\title{
SOCIAL ORDER AND EGG PRODUCTION OF HENS
}

\author{
by \\ E. H. VAN DIJKMAN, J. GROENEVELD, L. C. BRAT, \\ L. J. K. KLEIJN AND P. M. SCHENK \\ Farm Animal Behaviour Research T.N.O. \\ Zoological Laboratory of the University of Amsterdam
}

\section{INTRODUCTION:}

In a flock of hens the animals do not all occupy an equal position. A certain hierarchy exists - a social order - expressed by one hen dominating the other. This social order in hens - which is a peck-order was discovered by Scrjelderup-EbBe (1913) and its existence was confirmed by SANCTUARY (1932) and Masure and Allee (1934).

The simplest form of the peck-order is rectilinear: hen $a$ dominates all other hens, hen $b$ dominates all hens except one $(a)$ etc. and the peck-order ends with a hen which is dominated by all other hens (Fig. la). More complicated forms of peck-order also exist, which include "triangular relationships": a certain hen dominates another one with a higher position in the rectilinear peck-order (Fig. $1 b$ ).

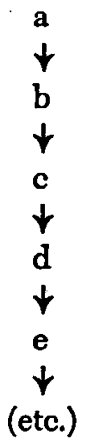

Fig. la. The peck-order is rectilinear.

Note: the direction of the arrows shows the line of dominance.

In small flocks a usually constant rectilinear peckorder results quite quickly (SCHJELDERUP-EBBE, 1935), but in large ones (of about 40 hens) it takes longer before the peck-order is stabilized and deviations from the rectilinear one - the "triangular relationships" described above - occur (Gurr, 1962). The hens recognize each other mainly by head and neck (Gurt, and Ortman, 1953; McBride, James and
SHOFFNER, 1963). In larger flocks the individual hens will not be able to recognize each other as easily, so that the peck-order is stabilized later and moreover changes in the peck-order can take place (GuHL, 1962).

A hen can show her dominance towards another hen by challenging behaviour (threatening), an attack (pecking) or "authoritative" behaviour (weak threatening) (PotTer and AlleE, 1953). While challenging (threatening) the hen has a tense body, somewhat bended legs, fluffed neck feathers and stuffed wings. In this attitude she circles round the other hen. The dominance of one hen over the other can be established by a fight, in which the opponents face each other with stretched necks, fluffed feathers and darkly coloured comb and gills. By jumping up they try to get on top of each other and peck each other. As soon as one of the hens runs away, she acknowledges the dominance of the other. Later on it is observed that the dominated hen avoids the other, runs away or flattens itself - in other words avoids a fight - as soon as she sees challenging behaviour (a threatening attitude) or "authoritative" behaviour (weak threatening) of the dominant hen. If the dominated hen does not run away quickly enough or avoid the other, she will be pecked (attacked) by the dominant hen.

So the aggressiveness of two hens is important for the peck-order which is effected between them. Collias (1943) found a positive correlation between aggressiveness and position in the peck-order (rank): the more aggressive the hen, the higher her rank. Accordingly Gunt (1953) considers the aggressive behaviour of the hens as the basis for the peck-order. This aggressiveness is especially demonstrated at the food trough, the drinker, the laying nest and during dusting. MCBrme (1958) also considers the aggressiveness of the hen important for establishing the peck-order. 
Whenever one or more hens are added to an already existing flock, the hens which originally inhabited the pen fight the newly introduced hens violently while there is little aggression between the original hens themselves (JAMES and FoENANDER, 1961). When hens are brougt into an as yet empty pen, they begin to feel at home quite soon after having looked round curiously for some time and after having pecked about.

This new pen is defended keenly against hens that are brought in later. Each newly introduced hen must conquer itself a position in the pen between the hens which consider the pen completely as their property (territory) (Collias, 1943; Gurl and AlleE, 1944). The newcomers are pecked violently and chased by the hens already present and therefore mostly get a low rank (Collias, 1944; GuHL, 1962).

It will be clear from this, that familiarity with the environment is also an important factor for the formation of the peck-order in a flock of hens. Hens, that have been in the pen longer and have a certain "right of seniority" (Gurt and AlleE, 1944) have an enormous advantage over the newcomers. The final peck-order in a flock is therefore determined by individual factors of the different hens (their aggressiveness) and by external factors that can be summed up as "familiarity with the environment". This "familiarity with the environment" is probably a complex of factors, which might be analyzed in a further research.

For a long time already investigators and breeders have been interested in the influence of the peckorder on the egg production of hens.

SANCtuary (1932) found, that there is a positive correlation between a hen's rank and her egg production. Hens at the top half of the peck-order lay more eggs than hens at the bottom half. The investigations of Gurt (1953) and MCBriDE (1958, 1960) confirmed this. McBride not only took the number of eggs as a measure for the egg production, but also their total weight during a certain period. Hens with a higher rank have a certain precedence at the food trough (MASURE and Allee, 1934; Gurr, 1945) so that hens with a lower rank can only eat when those with a higher rank have left the food trough. Colrias (1944) and GurL (1953) therefore ascertained that hens which have a low rank and are badly chased can hardly get at the food trough. They are only capable of getting at it in the twilight, when all other hens have eaten or are roosting. The low egg production of the hens with low rank could therefore directly be caused by a shortage of food (Collias, 1943; Gurh, 1953).

One could, however, also imagine that hens of lower rank show a worse general condition that cannot be ascribed directly to their feeding conditions. In this case the lesser egg production would not be a consequence of a lack of food, but - together with a lower aggressiveness - a direct result of their worse general condition, the lower rank thus not being - via the lack of food - the cause of the lower egg production.

If the egg production and the aggressiveness of the individual hens are determined primarily by their general condition, a positive correlation between egg production and rank can only be expected if the rank is the direct result of the aggressiveness of the hens. For a strong aggressiveness goes together with a high egg production and a weak aggressiveness with a low egg production. Moreover strong aggressiveness means a high rank and weak aggressiveness a low rank. However if the rank is chiefly determined by the factor of "familiarity with the environment", there will be no direct connection between egg production and rank. Hens which now have high ranks are not necessarily hens with the best general condition, while it is certainly possible that there are hens in the low ranks with a very good general condition. In that case there could be very bad egg layers among the hens with a high rank and good egg layers among the hens with a low rank.

A comparison of the egg production of a flock in which the establishment of the peck-order is strongly determined by "familiarity with the environment" with the egg production of a flock in which the influence of this external factor is eliminated, gives us the chance to choose between these two possibilities of influence on the egg production.

Whereas investigators on this problem occupied themselves up till now either with the study of the factors that determine the peck-order, or with the correlation between peck-order and production, it is mainly the purpose of the following experiment to investigate the correlation of all three groups of factors. It also gives the opportunity to investigate the special peck-order problems of a large flock of about 40 or 50 animals, while in earlier investigations as a rule with small flocks were worked with. In the following experiment a flock of hens was formed in which the factor of "familiarity with the environment" could play an important part during the formation of the peck-order. To this purpose the flock was divided into groups, that were brought into a 
new pen with intervals of about a week, so that there was a difference in familiarity with the pen between the groups that were brought in successively. Besides a flock of hens was formed, in which this factor did not play a part in the establishment of the peckorder. This flock was brought into a new pen as a whole, so that the surroundings were unknown to all hens at the same moment. Thus in this second flock the aggressiveness of the individual hens could play its part in the establishment of the peck-order. For both flocks the rank of each hen individually and her egg production was determined and thus a possible correlation between the final peck-order and the egg production could be found.

\section{MATERIALS AND METHOD:}

Two flocks of hens were used in the experiment. Both flocks consisted of the $F_{1}$ of a crossing of Rhode Island cocks and White Leghorn hens. The individual hens could be recognized by coloured and numbered metal plates, which were attached to both wings.

The first flock, consisting of 48 hens, was divided into 6 groups of 8 animals, which were marked with red, silver, black, green, blue and white plates respectively, numbered 1 to 8 . At the beginning of the experiment the hens of this flock were 8 months old. They were already laying well. The flock was built up step by step by putting a group of 8 animals in the testing pen with intervals of about a week, till the flock was complete. The 8 hens of each group were given their wing marks after they had been taken from the stock. Care was taken that the 8 animals of a group were caught from the stock arbitrarily. After the flock in the testing pen was completed, it was maintained there for about 6 months.

Afterwards the flock was taken into a second testing pen, which was also unknown to the hens. They were brought in in groups again, but contrariwise to the way they had been brought into the first pen; the group of hens that had been entered last into the first testing pen, was first brought in into the second pen, etc. The succeeding groups were brought into the second testing pen with intervals of 3 to 6 days. After this change the flock was observed for about another month. The scheme of the building and rebuilding of this flock is presented in table 1.

The second flock, consisting of 40 hens, was brought into the testing pen as a whole on 4/7/1964 and observed till $30 / 8 / 1964$. Moreover these hens were observed for a few hours a day during the period $24 / 11$ til $27 / 11 / 1964$. At the moment of putting the hens into the testing pen they were 3 months old. These hens only started laying during the course of the experiment.

The hens of this flock were marked with red, black, green and white plates, respectively, 10 hens with each colour. The 4 series of plates were numbered from 0 to 9 . The animals originated from two different pens, 20 hens, marked with red and green plates, came from one pen, and the other 20 hens, marked with black and white plates, came from another pen.

The peck-order in the flocks I and II was determined by the method described by GuHL (1945): pecks and obvious threatening attitudes were noted and a peckorder was put up according to the amount of other hens each animal pecked. The hen that pecks most other hens therefore figures at the top of the peckorder. Later on, from the end of march 1964 onwards, this method was somewhat modified. In the first place it was observed how many hens a certain hen pecks. Then it was determined by how many hens this hen was pecked. Acconding to the first criterion a hen has a high rank, if she pecks many other hens, according to the second criterion she has a high rank, if she is pecked by few other hens. The final peck-order is composed by combining these two peck-orders. For example, if a certain hen has the 12th rank according to the first and the 8th rank according to the second criterion, she will have the 10th rank in the combined, final peck-order. The use of this second method was necessary, because there are hens in a flock, that hardly peck at other ones and are hardly pecked by other ones. If the rank of these animals is only determined by the number of other hens they peck at, they will get a low rank. However the fact, that they are only pecked at by few other hens indicates, that they certainly should not be considered of low rank. The rank of such hens - called unclassified hens by PotTer and Allee (1953) - can perhaps better be determined by the method described by JAMEs and FoENander (1961), in which they were tested in an observation pen with one other hen only, so that the peck-order which exists between these two hens can be determined by the aggressiveness they exhibit towards each other. This method, however, could not be used because of the size of the flock.

The egg production of the hens was determined with 
so called trapnests, in which the hens shut up themselves as soon as they step in. Not only the individual production of the hens could be determined in this way, but, by inspecting the nests at every whole hour from 08.00 till 15.00 o'clock also the time of the day, at which the egg was laid and the nest in which the egg was deposited on a certain day. Date and number of the laying hen were written on the eggs, and for each egg it was also noted at which hour of the day it was laid and in which nest. Later on the eggs were weighed. Whenever eggs were laid outside the nests - which luckily rarely happened it was as a rule impossible to determine which hen was the layer. The egg production of flock I was noted from 18/11/1963 till 28/8/1964 and of flock II from 12/8/1964 till 4/11/1964.

The testing pens were of the same size for flocks I and II. They were arranged according to figure 2. Flock I had a tube feeder at its disposal. The size of the feeding pen - the part from which the hens could peck food - was made to agree with the number of hens in the pen. If there were only 8 hens, only $1 / 6$ th part of the feeding pen was at their disposal, if there were 16 animals $2 / 6$ th part, etc. till the feeding pen was open over its whole length, when all 48 hens were present in the pen.

Flock II received their food from an oblong food trough with perches on both sides, so that the hens were next to each other as well as facing each other while eating. The food trough was placed at a height of a half a meter above the ground. So the hens had to jump up to reach the perches. The amount of hours of daylight was complemented with electric light, so that the pens were always lighted from 05.00 o'clock a.m. till 19.00 o'clock p.m. Observations were made between 09.30 and 17.00 o'clock from a space adjoining the testing pen.

\section{ACKNOWLEDGEMENTS}

The experiments were executed at and with hens from the Central Institute for Poultry Research "Het Spelderholt" at Beekbergen. We wish to thank the head of this Institute, Mr. P. Ubbels and his coworkers, especially Messrs. J. Helder, J. van der Horst and E. Laseur for their excellent and extensive cooperation.

\section{RESULTS OF THE EXPERIMENT:}

\section{A. BUILD-UP OF FLOCK I:}

From a group of 48 hens, that had already been together in a pen from 29 October 1963 onwards (from now on called the stock pen), 8 arbitrary hens were

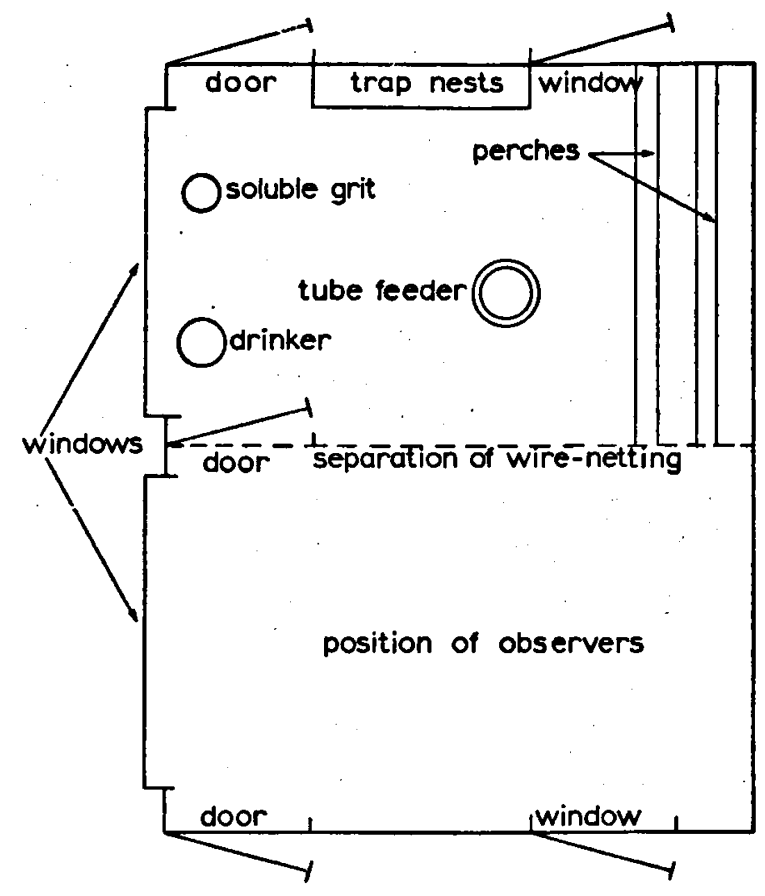

Fig. 2. Arrangement of experimental pen for flock I (for flock II the only difference was a different food trough, see text).

Trap nests: three rows of 5 nests on top of each other.

caught on 18th November 1963. These hens were provided with red plates with the numbers 1 to 8 (code: R. 1 to 8 ) and brought into the testing pen. At the moment of their being put into the testing pen these hens already knew each other and there must have existed already a certain peck-order among them. By observing the aggression between these hens the following peck-order could be ascertained after a few days:

\begin{tabular}{|c|c|c|c|c|c|}
\hline 苞 & 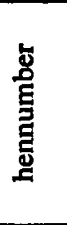 & 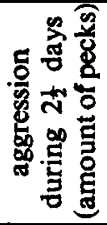 & 胥 & 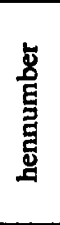 & 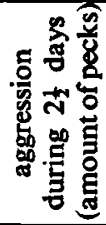 \\
\hline $\begin{array}{l}1 \\
2 \\
3 \\
4\end{array}$ & $\begin{array}{l}\text { R.4 } \\
\text { R.5 } \\
\text { R.2 } \\
\text { R.7 }\end{array}$ & $\begin{array}{r}113 \\
72 \\
39 \\
45\end{array}$ & $\begin{array}{l}5 \\
6 \\
7 \\
8\end{array}$ & $\begin{array}{l}\text { R.1 } \\
\text { R.6 } \\
\text { R.3 } \\
\text { R.8 }\end{array}$ & $\begin{array}{r}58 \\
9 \\
19 \\
2\end{array}$ \\
\hline
\end{tabular}

The amount of days, on which the peck-order was observed, is always mentioned under the heading of "aggression" in the tables given for the different periods of building up the flock. The amount of days 
is not the same for all periods of building up the flock, because the peck-order could be determined quickly in one period, while in another period it was necessary to make observations for a longer time. The two hens at the top of the peck-order are the most aggressive and the three hens at the bottom the least aggressive, in other words peck most, respectively least frequently, at other hens.

On 27th November 1963 a second group of 8 hens, arbitrarily caught from the stock and marked with silver plates, numbered from 1 to 8 (code: S. 1 to 8) were brought into the testing pen. According to the aggression observed the following peck-order could be determined between the 16 hens, now present in the testing pen:

\begin{tabular}{|c|c|c|c|c|c|}
\hline 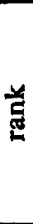 & 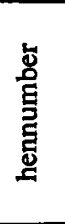 & 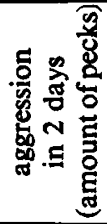 & 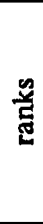 & 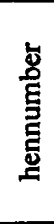 & 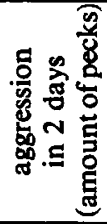 \\
\hline 1 & R.4 & 122 & 9 & R.6 & 16 \\
\hline 2 & R.5 & 77 & 10 & R.3 & 37 \\
\hline 3 & S.3 & 17 & 11 & R.8 & 29 \\
\hline 4 & S.8 & 19 & 12 & S.1 & 20 \\
\hline 5 & R.2 & 13 & 34 & S.4 & 17 \\
\hline 6 & R.7 & 77 & 14 & S. 5 & 3 \\
\hline 7 & S.6 & 43 & 15 & S.7 & 1 \\
\hline 8 & R.1 & 53 & 16 & S. 2 & 2 \\
\hline
\end{tabular}

On the day when the hens marked with silver plates were put into the testing pen, there only appeared to be aggression (pecking) from the side of the reds towards the silvers and no aggression at all between reds and silvers themselves. It is further remarkable, that 5 of the newcomers in the testing pen (the silvers) landed at the bottom of the peck-order.

The third group of 8 hens - again caught arbitrarily from the stock - was marked on 3rd December 1963 with black plates, numbered from 1 to 8 (code: Bl. 1 to 8 ) and then put into the testing pen. Once again the peck-order could be determined between the 24 hens, now present in the testing pen according to the observed aggression:

At first the newcomers (the hens marked with black plates) clustered together in a corner of the testing pen. Once again on the first day after putting in the blacks aggression was only observed from the side of the hens already present in the pen (the reds and the silvers) towands the newcomers (the blacks). It is again remarkable, that 6 of the blacks are found

\begin{tabular}{|c|c|c|c|c|c|}
\hline 弟 & 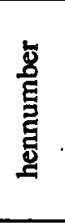 & 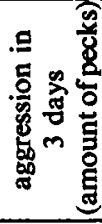 & 茝 & 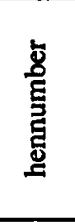 & 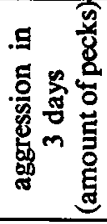 \\
\hline 1 & R.4 & 78 & 13 & R.3 & 62 \\
\hline 2 & R.5 & 66 & 14 & B1.7 & 25 \\
\hline 3 & S.3 & 42 & 15 & B1.1 & 12 \\
\hline 4 & S.8 & 117 & 16 & B1.2 & 3 \\
\hline 5 & R.2 & 62 & 17 & S.1 & 55 \\
\hline 6 & S.6 & 82 & 18 & S.4 & 48 \\
\hline 7 & R.7 & 65 & 19 & S.5 & 41 \\
\hline 8 & B1.8 & 98 & 20 & B1.4 & 8 \\
\hline 9 & B1.6 & 36 & 21 & S.7 & 28 \\
\hline 10 & R.1 & 65 & 22 & S.2 & 20 \\
\hline 11 & R.8 & 73 & 23 & B1.3 & 22 \\
\hline 12 & R.6 & 22 & 24 & B1.5 & 0 \\
\hline
\end{tabular}

at the bottom half of the peck-order, two even in the two lowest positions. It is further conspicuous, that two of the hens, already present in the testing pen, namely S.6 and R.8, climbed in the peck-order.

The fourth group of 8 hens - caught in the same manner as the preceding groups - was marked on 11th December 1963 with green plates, numbered from 1 to 8 (code: G. 1 to 8 ) and brought into the testing pen, so that there were 32 hens in the testing pen at that time. Once again mutual aggression between the hens was observed for a few days. According to the aggression the 32 hens were placed in the following peck-order:

\begin{tabular}{|c|c|c|c|c|c|}
\hline 䓂 & 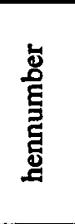 & 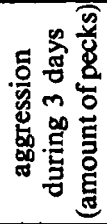 & 总 & 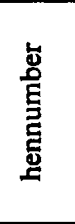 & 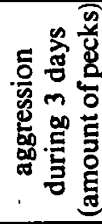 \\
\hline 1 & R.4 & 62 & 17 & B1.2 & 16 \\
\hline 2 & R. 5 & 31 & 18 & S.1 & 27 \\
\hline 3 & S. 3 & 11 & 19 & S.4 & 59 \\
\hline 4 & S.8 & 32 & 20 & G.7 & 38 \\
\hline 5 & R.2 & 25 & 21 & G.3 & 23 \\
\hline 6 & S.6 & 48 & 22 & S. 5 & 14 \\
\hline 7 & R.7 & 34 & 23 & B1.4 & 9 \\
\hline 8 & B1.8 & 72 & 24 & S.7 & 28 \\
\hline 9 & G.2 & 59 & 25 & G.6 & 21 \\
\hline 10 & B1.6 & 28 & 26 & S.2 & 18 \\
\hline 11 & R.1 & 36 & 27 & B1.3 & 14 \\
\hline 12 & R.8 & 54 & 28 & G.1 & 19 \\
\hline 13 & R.6 & 12 & 29 & G.8 & 8 \\
\hline 14 & R.3 & 17 & 30 & B1.5 & 14 \\
\hline 15 & B1.7 & 4 & 31 & G.5 & 0 \\
\hline 16 & B1.1 & 10 & 32 & G.4 & 0 \\
\hline
\end{tabular}


As after putting in the hens, marked with silver and black plates, there is only aggression from the hens (the reds, silvers and blacks) already present in the testing pen towards the newcomers (the greens) on the first day. No aggressiom was observed that day between the hens already present, between the newcomers themselves and from the newcomers towards the hens already present. The peck-order relations between the hens already present in the testing pen (the reds, silvers and blacks) had not changed as compared with that in the period of 27th November till 3rd December 1963. The newcomers all landed in the lower part of the peck-order except one (G.2.). Two of these hens (G.5 and G.4) even right at the bottom of the peck-order. Of the newcomers G.4 appeared to be ill, she had a bluish comb, limped, did not eat at all and did not lay any eggs. She was often chased by the other hens and tried to hide as much as possible. G.8 laid no eggs either.

On 18th December 1963 a fifth group of 8 hens, also caught as arbitrarily as possible from the 16 hens still present in the stock, is marked with blue plates, numbered from 1 to 8 (code: B.I to 8 ) and put into the testing pen. The flock, which now consisted of 40 hens was maintained as such till 6th January 1964. So there was twice as much time available for settling the peck-order as in the previous periods. The newcomers were all hardly aggressive, so it was difficult to determine their rank. According to the observed mutual aggression the following peck-order was determined finally between the $\mathbf{4 0}$ hens:

For the first time during the settling of the peckorder aggression was observed between the hens already present (the reds, silvers, blacks and greens) on the first day after bringing in the newcomers (the blues). The newcomers (the blues) again all landed at the bottom half of the peck-order, except one (B.7). Three of them (B.8, B.I and B.3) landed right at the bottom of the peck-order.

In the mutual peck-order relations between the hens already present (the reds, silvers, blacks and greens) there is hardly any change. Only G.4 climbs in rank at the cost of G.5. G.4 appeared to be reviving, she was eating again and started to lay eggs. G.8 on the other hand still had not started laying and B.1 did not lay any eggs either in the period, during which 40 hens were present in the testing pen.

After putting the last 8 hens from the stock into

\begin{tabular}{|c|c|c|c|c|c|}
\hline 를 & 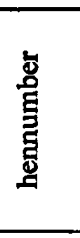 & 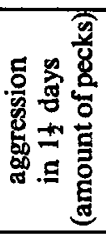 & 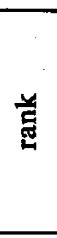 & 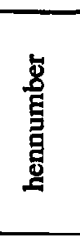 & 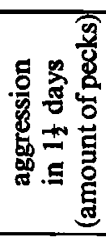 \\
\hline 1 & R.4 & 35 & 21 & G.7 & 12 \\
\hline 2 & R.5 & 1 & 22 & G.3 & 3 \\
\hline 3 & S.3 & 5 & 23 & B.2 & 2 \\
\hline 4 & S.8 & 18 & 24 & S.5 & 5 \\
\hline 5 & R.2 & 4 & 25 & B1.4 & 6 \\
\hline 6 & S.6 & 13 & 26 & S.7 & 21 \\
\hline 7 & R.7 & 10 & 27 & G.6 & 9 \\
\hline 8 & B1.8 & 11 & 28 & B.5 & 3 \\
\hline 9 & G.2 & 8 & 29 & S.2 & 9 \\
\hline 10 & B1.6 & 2 & 30 & B.4 & 1 \\
\hline 11 & R.1 & 8 & 31 & B1.3 & 8 \\
\hline 12 & R.8 & 6 & 32 & B.6 & 0 \\
\hline 13 & R.6 & 5 & 33 & G.1 & 4 \\
\hline 14 & R.3 & 6 & 34 & G.8 & 12 \\
\hline 15 & B1.7 & 3 & 35 & B1.5 & 11 \\
\hline 16 & B1.1 & 11 & 36 & G.4 & 3 \\
\hline 17 & B1.2 & 9 & 37 & B. 8 & 0 \\
\hline 18 & B.7 & 1 & 38 & B.1 & 0 \\
\hline 19 & S.1 & 2 & 39 & G.5 & 0 \\
\hline 20 & S.4 & 52 & 40 & B.3 & 0 \\
\hline
\end{tabular}

the testing pen on 6th January 1964, the building of the flock of 48 hens was completed. This 6 th group of 8 hens was marked with white plates, numbered from 1 to 8 (code: W. 1 to 8). All these hens landed at the bottom half of the peck-order except W.2. Three of them, W.8, W.7 and W.1 landed at the bottom. The flock was maintained like this till 6th July 1964.

It will be clear from this description of the building up of the flock, that newcomers always tend to land at the bottom of the peck-order. Further that up to the day on which the hens, marked with blue plates, were put into the testing pen, there was on the first day only aggression from the hens already present in the pen towards the newcomers. Calculating for the 6 groups of which the flock consists (the reds, silvers, blacks, greens, blues and whites), the mean rank which each group of 8 hens occupies in the successive periods during and after the building up of the flock, the results given in Table 2 are obtained. The mean ranks of the 6 groups for the periods of 6th January till 24th March 1964, 24th March till 1st May 1964 and 1st May till 2nd July 1964 have been calculated from the peck-order data, given in the tables 3, 4 and 5 respectively.

From Table 2 it is clear that during the building up of the flock the newly added groups of hens al- 
ways occupy the lowest mean rank. It is also clear that the difference in mean rank between the hens already present is maintained. The group that was brought in first (the reds) maintains the highest mean rank during the whole build-up of the flock, the group brought in as the second group the next highest, etc. These differences are also maintained during the first period in which the flock as a whole is in the testing pen (the period of 6th January till 24th March 1964). If, however, the flock as a whole stays in the testing pen for a longer period, changes take place in the peck-order, so that e.g. in the last period (1st May till 2nd July 1964) the blacks and the whites have a higher mean rank than the silvers and the blues. However, the hens of the group that was first brought in (the reds) appeared to be able to maintain their high mean rank till the end. Generally speaking, the mean rank of the groups that were brought in later remains lower during the whole time.

\section{B. FLOCK I PRESENT AS A WHOLE:}

As has been said before, flock I was present in the testing pen as a whole from the 6th January 1964 till 6th July 1964. A peck-order was drawn up for this flock during the period of 6th January till 24th March 1964, based only on the amount of hens that were pecked at. In the periods of 24th March till 1st May and 1st May till 2nd July 1964 the peck-order was based on the amount of hens a certain hen pecked at and the amount of hens this hen was pecked by. For this see the explanation under "Materials and method" on the pages 83 and 84. The peck-orders determined in the first period and in the second and third periods are therefore not quite comparable. Moves in the peck-order are certainly for a part the result of the different way of determining the peckorder in the different periods. The peck-order for the three periods is given in the tables 3,4 and 5, while the egg production - expressed in amount of eggs, mean egg weight and total amount of egg kilograms (total egg weight) - during the period concerned, is also noted.

Finally a figure is given in the tables for the aggressiveness of the different hens, which is based on the amount of pecks the different hens distribute during certain periods of observation.

From Table 3 can be read that during the period of the 6th January till 24th March 1964 the hens in the top half of the peck-order lay more eggs and produce a higher total egg weight than the hens in the bottom half. These differences in egg production between the hens of the top and the bottom half of the peckorder are significant (for the amount of eggs: $p<0.01$; for the total egg weight: $\mathrm{p}<0.05$ ). The difference in mean egg weight between the first and the last 24 hens is not significant $(p>0.05)$. The correlations are determined between the peck-order and the number of eggs, the mean egg weight and the total egg weight. These are:

correlation peck-order - number of eggs: +0.363 sign. $(\mathrm{p}<0.05)$

correlation peck-order - mean egg weight: +0.182 not sign.

correlation peck-order - total egg weight: +0.270 not sign.

A significant positive correlation for this period therefore exists between the peck-order and the number of eggs. In other words the higher a hen's rank, the more eggs she lays. The difference in aggressiveness that exists between the 24 highest hens and the 24 lowest hens in the peck-order appears to be significant $(p<0.005)$. The correlation between peck-order and aggressiveness has not been calculated for this period.

During the period of 24th March till 1st May (see table 4) the hens from the top half of the peck-order also lay more eggs with a higher total egg weight than the hens at the bottom half. Here only the difference in number of eggs between the first and last 24 hens appeared to be significant $(p<0.05)$. The difference in aggressiveness between the two groups is again significant for this period $(\mathrm{p}<0.001)$.

The calculated correlations between peck-order and number of eggs, mean egg weight and total egg weight during the period of 24th March till 1st May are respectively:

correlation peck-order - number of eggs: +0.371 sign. $(\mathrm{p}<0.01)$

correlation peck-order - mean egg weight: +0.326 sign $(p<0.05)$

correlation peck-order - total egg weight: +0.352 sign. $(\mathrm{p}<0.05)$

All correlations are positive and significant here, which means that hens produce more eggs with a higher egg weight, the higher their rank, while the totally produced egg weight is also higher.

During this period the correlation between peckorder and aggressiveness was calculated. This is +0.599 and is significant $(\mathrm{p}<0.01)$. The hens with a higher rank obviously show a greater aggressiveness. 
The data on peck-order, egg production and aggressiveness over the third period - from 1st May till 2nd July - are finally noted in table 5. During this period only the difference in aggressiveness between the 23 highest and 23 lowest hens in the peck-order appears to be significant $(p<0.05)$. The calculated correlations between peck-order and number of eggs, mean egg weight and total egg weight partly show another image:

correlation peck-order - number of eggs: +0.327 sign. $(\mathrm{p}<0.05)$

correlation peck-order - mean egg weight: +0.238 not sign.

correlation peck-order - total egg weight: +0.332 sign. $(\mathrm{p}<0.05)$

It appears again from these correlations, that the higher the hen's rank, the more eggs she lays with a higher total egg weight. The mean egg weight is on the other hand not significantly influenced by the rank.

The calculated correlation between peck-order and aggressiveness is $\mathbf{+ 0 . 5 2 2}$ for this period and is significant $(p<0.01)$. Also during this period the hens are more aggressive the higher their rank.

Resuming the above, it can be said, that during the whole period in which the hens of flock I were together in the testing pen, the egg production of the hens is greater, the higher their rank: either because only a greater number of eggs is laid, or because both a greater number of eggs is laid and the totally produced egg weight is greater.

The mean egg weight is probably not influenced by the rank: the difference in mean egg weight between the first and the last 24 hens in the peck-order is not significant in any of the three periods, while a significant positive correlation between peck-order and mean egg weight was only found once. Finally it becomes clear again and again that the aggressiveness of the hens is greater, the higher their rank. Both the difference in aggressiveness between the first and the last 24 hens in the peck-order and the positive correlation between rank and aggressiveness are always significant.

Because there is such a strong correlation between rank and aggressiveness, while moreover the egg production of a hen is connected with her rank, there will be sense in determining the relation between the aggressiveness of the hens and their egg production. To this purpose the hens are arranged in a series according to their aggressiveness, with the hen that pecks most as the first, etc. Then the correlations were calculated between the aggressiveness and the number of eggs, the mean egg weight and the total egg weight for the periods of 24th March till 1st May and 1st May till 2nd July 1964. These correlations are:

24th March till 1st May and 1st May till 2nd July aggressiveness - number of eggs:

$$
\begin{aligned}
& \quad+0.381 \text { sign. }(\mathrm{p}<0.01) ;+0.399 \text { sign. }(\mathrm{p}<0.05) \\
& \text { aggressiveness - mean egg weight: } \\
& \quad+0.332 \text { sign. }(\mathrm{p}<0.05) ;+0.124 \text { not sign. } \\
& \text { aggressiveness - total egg weight: } \\
& \quad+0.337 \text { sign. }(\mathrm{p}<0.05) ;+0.317 \text { sign. }(\mathrm{p}<0.05)
\end{aligned}
$$

From these correlations it appears that the hens lay more eggs during both periods with a larger total weight, the more aggressive they are. Moreover the more aggressive hens lay heavier eggs on the average in the first period.

Three conclusions can be drawn from the preceding: 1. The hens show a better egg production, expressed in a greater number of eggs and a higher total egg weight, the higher their rank.

2. A high rank is correlated with strong aggressiveness, a low rank with weak aggressiveness.

3. As their aggressiveness increases the hens show a better egg production, again expressed in a greater number of eggs and a higher egg weight.

\section{REBUILD OF FLOCK I:}

After the hens of flock I had been together for 6 months, the flock was transferred in groups to a second testing pen from 6th July onwards. This pen was arranged in the same manner as the first testing pen (see Figure 2). The transfer was effected so, that the group that was brought in first was the group that had been brought into the first testing pen last (the whites), etc. The order of transfer was therefore: first the whites, then the blues, the greens, the blacks and the silvers and finally the reds. The hens stayed together in the first testing pen till they were transferred to the second testing pen. The peck-order in this pen, therefore, was maintained so that at the moment of transfer the peck-order in the group that was brought in was already determined. The scheme of the transfer is shown in Table 1. Because of shortage of time the rebuild of the flock had to be less regular than the building up: 3 days after putting the whites into the second testing pen, the blues were added, 5 days after the blues the greens, 3 days 
after the greens the blacks, 6 days after the blacks the silvers and after another 6 days the reds.

The change in rank during the rebuild of the flock is demonstrated (Table 6) by the mean rank of the groups during the succeeding periods in which the whites and the blues, the whites, the blues and the greens etc., were together in the second testing pen. We first give the peck-order as it was settled, when only the whites and the blues were in the second testing pen (period of 9th July till 14 July 1964):

\begin{tabular}{|c|c|c|c|c|c|}
\hline 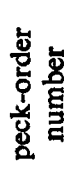 & 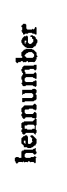 & 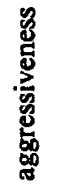 & 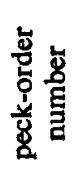 & 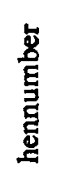 & 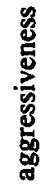 \\
\hline 1 & W.2 & 225 & 8 & B.4 & 52 \\
\hline 2 & W.1 & 133 & 9 & B. 3 & 19 \\
\hline 3 & W.4 & 84 & 10 & W.8 & 45 \\
\hline 4 & W.6 & 143 & 11 & B.6 & 11 \\
\hline 5 & W.3 & 34 & 12 & B.1 & 29 \\
\hline 6 & B. 8 & 100 & 13 & B. 5 & 2 \\
\hline 7 & B. 2 & 58 & 14 & W.7 & 9 \\
\hline
\end{tabular}

Note: W. 5 and B. 7 had died

We find the same phenomenon here as during the build-up of flock $\mathrm{I}$. The hens that where brought into the pen first (the whites) occupy the highest mean ranks. Further the hens with the highest ranks appear to be the most aggressive on the average.

In Table 6 the mean ranks of the 6 groups are given respectively before the rebuild of the flock, during the periods that successively two, three, four and five groups were together during the rebuilding of the flock and lastly after the rebuild of the flock. From this table it appears: 1 . Especially the mean rank of the whites has increased considerably after the rebuild (from 30 to 17), 2. Besides, the mean rank of the greens has increased (from 28 to 23) and 3. The mean rank of the reds has decreased considerably (from 9 to 18 ).

Thus, as a result of rebuilding the flock, changes have taken place in the mean ranks of the groups in such a manner, that the mean rank of the hens, that were first brought into the second testing pen (the whites) has increased as compared to that of all other groups, while the hens that were brought in last (the reds) occupy a much lower rank. After the rebuild of the flock the whites occupy the highest mean rank.
The peck-order of flock I, as it was settled after the rebuilding of the flock, was determined during the period of 29th July to 26th August 1964 and is given in Table 7. The egg production is also given in this table, again expressed in number of eggs, mean egg weight and total egg weight. Moreover a figure has been given for the aggressiveness of the individual hens, dependent on the number of times they pecked at another hen.

The egg production, given in Table 7 has been determined over the period of 1st July till 27th August 1964. Half of the period during which the egg production was determined lies therefore before and during the rebuild of flock I, which could possibly weaken the relation between the peck-order and the egg production after the rebuild of the flock. It would have been better to determine the egg production after rebuilding the flock during a longer period. Due to circumstances, however, it was not possible to keep flock I under further control after 26th August 1964.

The 21 hens with the highest ranks laid more eggs than the 21 hens with the lowest ranks, with a higher total egg weight. These differences in number of eggs and total egg weight are significant (for the number of eggs: $p<0.05$; for the total egg weight: $\mathrm{p}<0.05$ ). The small difference in mean egg weight between the two groups is not significant.

Table 7 further shows that there is a considerable difference in aggressiveness between the first and the last 21 hens in the peck-order. The first 21 hens together show a much stronger aggressiveness than the last 21 hens. The difference in aggressiveness between both groups is significant $(p<0.01)$. The correlations between peck-order and egg production for the period of 29th July till 27th August 1964 are:

correlation peck-order - number of eggs:

$$
+0.462 \text { sign. }(p<0.01)
$$

correlation peck-order - mean egg weight:

$$
+0.239 \text { not sign. }
$$

correlation peck-order - total egg weight:

$$
+0.464 \text { sign. }(p<0.01)
$$

From these correlations it again results that the hens with a higher rank lay more eggs with a higher total eight weight. Here again the mean egg weight does not appear to be influenced distinctly by the rank.

The calculated correlation between rank and aggressiveness is +0.503 and is significant $(p<0.01)$. The hens therefore are the more aggressive the higher their rank. 
Again there is a strong correlation between rank and aggressiveness. Therefore again the correlations between the aggressiveness of the hens and their egg production have been determined, viz.:

$$
\begin{aligned}
& \text { correlation aggressiveness - mumber of eggs: } \\
& +0.363 \text { sign. }(\mathrm{p}<0.05) \\
& \text { correlation aggressiveness - mean egg weight: } \\
& +0.067 \text { not sign. } \\
& \text { correlation aggressiveness - total egg weight: } \\
& +0.354 \text { sign. }(\mathrm{p}<0.05)
\end{aligned}
$$

The egg production of the hens - expressed in number of eggs and total egg weight - increases apparently with their aggressiveness. On the contrary the mean egg weight is not clearly influenced by the aggressiveness.

Summing up, we can say:

1. The peck-order in flock I has changed through the rebuild of the flock, the mean ranks of the hens that were brought in first increased strongly and the mean ranks of the hens that were brought in last decreased strongly.

2. After the rebuild of the flock the egg production of the hens appears to be correlated with their new rank: a higher rank is connected with a better egg production (expressed in number of eggs and total egg weight).

3. The correlation between peck-order and aggressiveness is of the same kind before and after the rebuilding of the flock: a higher rank is always correlated with a stronger aggression.

4. The correlation between aggressiveness and egg production is of the same kind before and after the rebuilding of the flock: a stronger aggressiveness of the hens is correlated with a better egg production (expressed in number of eggs and total egg weight). 5. After the rebuilding of the flock again no clear correlation existed between the hen's rank and the mean weight of her eggs. There is no clear correlation either between the aggressiveness of the hens and the mean weight of their eggs.

\section{PECK-ORDER AND EGG PRODUCTION OF FLOCK II:}

The 40 hens of flock II were all together brought into the testing pen. This flock differs from flock I also in the age of the hens: at the beginning of the experiment they were 3 months old. The origin of the hens and the way the animals were marked individually, are described on pages 83 and 84 . Flock II had a type of food trough differing from that of flock $I$ : an oblong food trough at a height of about half a metre above the ground of the pen. A hen had to jump up to get at the food, so that it was impossible for her to determine next to which hen she would land, because she only saw the back side of the other hens, this being insufficient for individual recognition. Indeed the hens recognize each other mainly by head and neck (Gurl and Ortman, 1953.) So it could easily happen, that a hen landed on the perch next to a hen with a higher rank, which hen then would force her to leave. Indeed it was often observed in this flock that a hen was chased off the food trough by her neighbour as soon as she had jumped onto it.

On the food trough the hens could see each other both from the side and from the front. The mutual aggression appeared to be mainly towards the side and only in a few cases towards the front. The hens that faced each other - on both sides of the food trough - were probably too far away still to release mutual aggression. In Table 8 the peck-order of flock II is given as it could be established during the period of 4th July till 31st August 1964. The observations, made for 3 days in November 1964, showed a peck-order which on the whole agreed with the peck-order given in Table 8.

Further data in this table, as measures for the egg production, are the number of eggs laid by the different hens and the mean and total egg weight of those eggs. The egg production of flock II was determined from 12th August till 5th November 1964, because the hens had hardly started laying at the beginning of the experiment (on 4th July 1964).

Finally a measure for the aggressiveness of each hen is given in Table 8. This measure is based on the amount of times a hen pecks at another one.

Comparing the egg production of the 20 hens with the highest ranks with the egg production of the 20 with the lowest ranks, it appears that the first group as a whole produces more eggs with a higher total egg weight than the second group, while the mean egg weight of the first group is also somewhat higher. The differences between the first and the last group are however neither significant for the number of eggs, nor for the mean egg weight, nor for the total egg weight. For flock II no clear difference in egg production could therefore be shown between the first and the last 20 hens in the peck-order.

However the difference in aggressiveness between the first and the last 20 hens in the peck-order is significant $(p<0.05)$. The hens with the 20 highest ranks are clearly more aggressive than the hens with the 20 lowest ranks.

For flock II the correlations were also computed 
between the peck-order and the number of eggs, the mean egg weight and the total egg weight, viz.:

correlation peck-order - number of eggs:

correlation peck-order - mean egg weight:

+0.199 not sign.

correlation peck-order - total egg weight: +0.219 not sign. +0.201 not sign.

For flock II therefore no clear correlation could be shown between peck-order and egg production: in this flock the hens with a higher rank did not clearly lay more eggs, while also the mean egg weight and the total egg weight did not increase distinctly.

The correlation between rank and aggressiveness is 0.516 and is significant $(\mathrm{p}<0.01)$. Thus the hens of flock II were clearly more aggressive, the higher their rank.

The correlations calculated between aggressiveness and egg production (number of eggs, mean and total egg weight) are not significant either. These are:

correlation aggressiveness - number of eggs: +0.038 not sign.

correlation aggressiveness - mean egg weight: +0.159 not sign.

correlation aggressiveness - total egg weight: +0.016 not sign.

No clear correlation could either be shown for flock II between aggressiveness and egg production. The egg production of the hens does not increase clearly with their aggression. Thus the results obtained with flock II only agree with those of flock I in the strong correlation between peck-order and aggression: for both flocks strong aggression appears to be correlated with a high rank and weak aggression with a low rank.

For both, flock I and flock II, the aggressiveness was shown most clearly in the neighbourhood of the food trough. At other places in the pen the hens also pecked at each other, but less frequently and certainly less severely than at the food trough.

\section{DISCUSSION.}

From the preceding it has become clear that the factor of "familiarity with the environment" plays an important part in the establishment of the peck-order in a flock of hens, that is built up step by step by continually adding new groups to the hens, already present in a pen. The hens that are first present in the pen occupy the highest ranks in this flock. The importance of this factor for the establishment of the peck-order becomes even more clear if we consider the changes in the peck-order of a flock of hens that have been together for 6 months, when this flock is built up anew. During the rebuild of flock $I$ it again became clear, that the time at which the hens were brought into the new pen, was of great influence on their rank. The hens that had been transferred first had changed their ranks considerably as compared with all other groups. Between the other groups the rank relations are influenced less strongly after the rebuild of the flock. This is probably connected with the rate at which the flock is brought into the new pen. It is known from the literature, that hens still know each other after separation of less than two weeks (Schjelderup-EbBe, 1935). Only the hens of the first and last group of the flock were separated long enough during the rebuild of the flock to eliminate mutual recognition of the groups (more than three weeks passed between the bringing in of these two groups into the new testing pen). Between these two groups there is a clear reversal in the rank relations after rebuilding the flock. The results of the investigation therefore confirm the ideas of Colliss (1944) and Gurl and Allee (1944), according to which authors the hens already present in the pen can show a certain "right of seniority" towards the newcomers, which then results in a higher rank. For both flocks it appeared, that higher ranks go together with a greater aggressiveness, as was also found by earlier investigators. Whereas in flock I the peckorder was determined in the first place by environmental factors, it is impossible to ascribe the higher rank to the stronger aggression in the first place. Familiarity with the environment of the hens already present is the cause of their aggressive behaviour towards newcomers: they defend the environment they consider their property against intruders (Colluss, 1943). These do not yet feel at home in the to them as yet unknown surroundings, which is why their aggression is indeed strongly suppressed. In fact we frequently saw that during the build-up of flock I aggression only was shown by the hens already present towards the newcomers on the day a new group was brought into the testing pen.

For flock I a clear correlation appeared to exist between the rank of the hens and their egg production, the egg production increasing with the height of the hen's rank, as was also demonstrated by earlier investigators. At the same time a clear correlation could be demonstrated for flock I between the aggressiveness of the hens and their egg production. The better egg production is expressed in both cases 
by a larger amount of eggs with a higher total egg weight. The mean egg weight on the other hand does not show a clear connection with the rank or the aggressiveness of the hens.

Now the peck-order in flock $I$ is for an important part determined by the factor of "familiarity with the environment" and only incompletely reflects the physical qualities of the hens. In other words a less lively hen can take a higher rank in flock $I$, only because she was brought into the testing pen as one of the first hens and contrariwise a lively hen can have a low rank, because she was brought into the testing pen at a later time. As we know, the egg production in flock $I$ is strongly connected with the rank and the general aggressiveness, as to the number of eggs and the total egg weight. We therefore suppose that the egg production of flock I as to amount of eggs and total egg weight is not an expression of the vitality of the individual hens, but is indirectly determined by the aggressiveness of the hens. The more aggressive hens frequently prevent the less aggressive hens to get to the food trough. Indeed we saw that the mutual aggression is especially strong in the neighbourhood of the food trough. The less aggressive hens, therefore, have les chance to eat, which is then again expressed in a smaller egg production: the hens lay fewer eggs and therefore produce a lower total egg weight. The results of the investigation therefore confirm the ideas of Collias (1943) and Gurr (1953), who both assumed, that the lower egg production of the hens with a low rank is the result of a shortage of food. On the contrary the mean egg weight appears to be hardly dependent on rank and strength of aggressiveness. The weight of the eggs is therefore more an individual quality of the hens, probably strongly determined genetically.

For flock II no clear correlation was found between rank and egg production and between aggressiveness and egg production. This is probably connected with the age of these hens. The hens of this flock were only 3 months old at the beginning of the experiment and for a part only started laying during the experiment. Their egg production had not yet been stabilized. The hens of flock I were already 8 months old when the experiment started and their egg production was stabilized by then. The relation between egg production and rank and between egg production and aggressiveness can only be clearly demonstrated when the egg production has become regular and has reached a certain constant value. The fact that this flock did not undergo any changes from the beginning and therefore might perhaps be calmer than flock I, can to our opinion not be used as an explanation for the above, as different authors (McBride, 1958; Sanctuary, 1932) did show a correlation between rank and production for such flocks.

The peck-order of flock II will have been determined stronger by the physical and behavioural qualities of the individual hens than that of flock I. Indeed for flock II the environmental factors were the same for all hens from the beginning of the experiment, because the flock was brought into the testing pen as a whole.

For neither of the flocks the peck-order was completely stable and rectilinear. In the period that the hens of flock I were present in the testing pen together a number of changes occurred in the peckorder, which however hardly influenced the mean ranks of the groups of which flock I was composed.

In flock II also a few minor changes in the peckorder occurred in the course of time. In both flocks moreover so-called "triangular relationships" were observed, such as those described in the introduction. As to stability and formation of the peck-order, our results therefore confirm the remarks of Gurl (1953) about the peck-order in large flocks.

\section{SUMMARY:}

1. For two flocks of 48 and 40 hens, consisting of the $F_{1}$ of Rhode Island Red males and White Leghorn females, peck-order, aggressiveness and egg production were determined. Flock I was built up step by step by continually adding a group of 8 hens to the hens already present in the testing pen. Flock II was brought into the testing pen as a whole at once.

2. The peck-order of the hens of flock I was clearly correlated with the date they had been put into the testing pen. The earlier the hens came into the testing pen, the higher their ranks. When the flock was rebuilt so that the groups were brought into the pen in reversed order, this correlation between peck-order and date of introduction into the pen was found again.

3. In flocks I and II a clear correlation between peck-order and aggressiveness existed, higher rank being correlated with stronger aggressiveness.

4. The peck-order, settled in flock I must have been determined for an important part by environmental factors, which can be summed up as "familiarity with the environment". The peck-order of flock II must on the contrary have been mainly dependent on the physical and behavioural characteristics of the individual hens, because the environmental factors were equal here for all hens from the beginning. 
The hens were all brought into the testing pen together.

5. In flock I a clear correlation existed between peck-order and egg production. Hens with a higher rank laid more eggs and produced a higher total egg weight. The same correlation exists between aggressiveness and egg production. A stronger aggression is correlated with a higher egg production.

6. The correlation between peck-order and aggression on the one hand and the egg production on the other hand runs through the feeding possibilities.
The less aggressive hens get less food, because they are regularly chased from the food trough by the more aggressive hens. This shortage of food leads to a decreased egg production.

7. For flock II no clear correlation could be shown between peck-order and aggressiveness on the one hand and the egg production on the other hand. It is probable that the egg production of this flock started during the experiment and, therefore, was not yet properly stabilized.

\section{REFERENCES}

Collias, N. E., 1943: Statistical analysis of factors which make for success in initial encounters between hens. Am. Natur. 77, p. 519-538.

- 1944: Aggressive behavior among vertebrate animals. Physiol. Zool. 17, p. 83-123.

GuHL, A. M., 1945: Some observations and experiments on social behavior in the domestic fowl. Transact. Kansas Acad. Sci. 47, p. 335-341.

- 1953: Social behavior of the domestic fowl. Techn. Bull. Agric. Exp. Stat. Kansas 73, p. 1-48.

- 1962: The behaviour of chickens. In: Hafez, E.S.E.ed. The behaviour of domestic animals. Baillière, Tindall and Cox, London, 1962, p. 491 e.v.

GuHL, A. M., and W. C. AlleE, 1944: Some measurable effects of social organisation in the flocks of hens. Physiol. Zool. 17, p. 320-347.

GuhL, A. M., and L. L. Ortman, 1953: Visual patterns in the recognition of individuals among chickens. The Condor 55, p. 287-298.

JAMES, W., and F. FoenANDER, 1961: Social behaviour studies on domestic animals. Austral. J. Agric. res. 12, p. 1239-1252.

Masure, R. H., and W. C. Allee, 1934: The social order in flocks of the common chicken and pigeon. Auk 51, p. 306-325.

MCBRIDE, G., 1958: Relationship between aggressiveness and egg production in the domestic hen. Nature 181, p. 858 .

- 1960: Poultry husbandry and the peck order. Brit. Poult. Sci. 1, p. 65-68.

McBride, G., JAMes, J. W., and R. N. Shoffner, 1963: Social forces determining spacing and head orientation in a flock of domestic hens. Nature 197, p. 1272-1273.

PotTer, J. H., and W. C. Allee, 1953: Some effects of experience with breeds of Gallus gallus $\mathrm{L}$. on behavior of hens towards strange individuals. Physiol. Zool. 16, p. 147-161.

SANCtUARY, W. C., 1932: A study of avian behavior to determine the nature and persistency of the order of dominance in the domestic fowl and to relate these to certain physiological reactions. M. S. Thesis, Mass. State Coll. Amherst. (cited by McBride, 1958).

SCHJelderUP-EBbe, T., 1913: Hönsenes Stemme. Bidrag til hönsenes psykologi. Naturen 37, p. 262-276.

- 1935: Social behaviour in birds. In: Murchison's Handbook of Social Psychology, chapter 20, Murchison, C. (ed.), Worcester, Mass.: Clark University Press. 


\begin{tabular}{|c|c|c|}
\hline \multicolumn{3}{|c|}{ I. Hens in the first experimental pen } \\
\hline period: & hens in pen were marked: & number \\
\hline $18 / 11-26 / 111963$ & R.1 - 8 & 8 \\
\hline $27 / 11-2 / 121963$ & $\mathbf{R . 1}-8 ; \mathbf{S} .1-8$ & 16 \\
\hline $3 / 12-10 / 121963$ & $\mathrm{R} .1-8 ; \mathrm{S} .1-8 ; \mathrm{Bl} .1-8$ & 24 \\
\hline $11 / 12-17 / 121963$ & R.1-8; S.1 - 8; Bl.1 - 8; G.1 - 8 & 32 \\
\hline $18 / 121963-5 / 1^{\prime} 64$ & R.1 - 8; S.1-8; Bl.1-8; G.1 - 8; B.1-8 & 40 \\
\hline $6 / 1-30 / 41964$ & R.1-8; S.1 - 8; Bl.1-8; G.1-8; B.1-8; W.1 - 8 & 48 \\
\hline 1/5-5/7 1964 & the same hens as in the prexeding perio d except W.5 and G.8(both had died) & 46 \\
\hline \multicolumn{3}{|c|}{ II. Hens in the second experimental pen: } \\
\hline period: & the hens present in this pen were marked: & number: \\
\hline $6 / 7-8 / 71964$ & W.1 $-4 ; W .6-8$ & 7 \\
\hline $9 / 7-13 / 71964$ & W.1 - 4; W.6-8; B.1 - 6; B.8 (B.7 had died) & 14 \\
\hline 14/7-16/7 1964 & W.1 - 4; W.6-8; B.1 - 6; B.8; G.1 - 7 & 21 \\
\hline $17 / 7-22 / 71964$ & W.1 - 4; W.6-8; B.1 - 6; B.8; G.1 - 7; B1.1 - 8 & 29 \\
\hline $23 / 7-28 / 71964$ & W.1 - 4; W.6-8; B.1-6; B.8; G.1 - 7; B1.1-8; S.1-8 & 37 \\
\hline 29/7-26/8 1964 & $\begin{array}{l}\text { W.1 - 4; W.6-8; B.1-4; B.6; B.8; G.1 - 7; Bl.1-8; S.1 - 8; } \\
\text { R.1; R.3-6; R.8 (B.5, R.2 and R.7 had died) }\end{array}$ & 42 \\
\hline
\end{tabular}

$\mathbf{R}=$ hens marked with red plates; $\mathbf{S}=$ with silver plates; $\mathbf{B l}$. $=$ with black plates; $\mathbf{G}=$ with green plates; $\mathbf{B}=$ with blue plates; $\mathbf{W}=$ with white plates.

Table 1. Building and rebuilding of flock I during the experiment.

\begin{tabular}{|c|c|c|c|c|c|c|c|}
\hline \multirow[b]{2}{*}{ period } & \multirow[b]{2}{*}{ groups of hens present } & \multicolumn{6}{|c|}{ mean rank of group: } \\
\hline & & $\begin{array}{l}\text { reds } \\
\text { (R.) }\end{array}$ & $\begin{array}{c}\text { silvers } \\
\text { (S.) }\end{array}$ & $\begin{array}{c}\text { blacks } \\
\text { (Bl.) }\end{array}$ & $\begin{array}{c}\text { greens } \\
\text { (G.) }\end{array}$ & $\begin{array}{c}\text { blues } \\
\text { (B.) }\end{array}$ & $\begin{array}{c}\text { whites } \\
\text { (W.) }\end{array}$ \\
\hline $\begin{array}{l}27 / 11-2 / 12^{\prime} 63 \\
3 / 12-10 / 12^{\prime} 63 \\
11 / 12-17 / 12^{\prime} 63 \\
18 / 12{ }^{\prime} 63-5 / 1^{\prime} 64 \\
6 / 1-23 / 3^{\prime} 64 \\
24 / 3-30 / 4^{\prime} 64 \\
1 / 5-1 / 7^{\prime} 64\end{array}$ & $\begin{array}{l}\text { R; S. } \\
\text { R.; S.; Bl. } \\
\text { R.; S.; Bl.; G. } \\
\text { R.; S.; Bl.; G.; B. } \\
\text { R.; S.; Bl.; G.; B.; W. } \\
\text { R.; S.; Bl.; G.; B.; W. } \\
\text { R.; S.; Bl.; G.; B.; W. }\end{array}$ & $\begin{array}{r}6.5 \\
7.6 \\
8.1 \\
8.1 \\
9.1 \\
10.1 \\
9.0\end{array}$ & $\begin{array}{l}10.5 \\
12.5 \\
15.3 \\
16.4 \\
17.8 \\
20.8 \\
22.1\end{array}$ & $\begin{array}{l}\overline{16.1} \\
18.3 \\
19.5 \\
19.5 \\
21.4 \\
17.7\end{array}$ & $\begin{array}{l}- \\
\overline{24.5} \\
27.4 \\
29.8 \\
28.0 \\
28.0\end{array}$ & $\begin{array}{l}- \\
\overline{-} \\
30.8 \\
33.1 \\
33.0 \\
33.0\end{array}$ & $\begin{array}{l}- \\
- \\
37.9 \\
33.8 \\
30.0\end{array}$ \\
\hline
\end{tabular}

Table 2. Mean rank of the six groups of flock I during and after building the flock. 


\begin{tabular}{|c|c|c|c|c|c|c|c|c|c|c|c|}
\hline $\begin{array}{l}\text { hen } \\
\text { nr. }\end{array}$ & rank & $\begin{array}{l}\text { number } \\
\text { of eggs }\end{array}$ & $\begin{array}{c}\text { average } \\
\text { egg } \\
\text { weight } \\
\text { (grams) }\end{array}$ & $\begin{array}{c}\text { total egg } \\
\text { weight } \\
\text { (kgrams) }\end{array}$ & $\begin{array}{l}\text { aggres- } \\
\text { siveness }\end{array}$ & $\begin{array}{l}\text { hen } \\
\text { nr. }\end{array}$ & rank & $\begin{array}{l}\text { number } \\
\text { of eggs }\end{array}$ & $\begin{array}{c}\text { average } \\
\text { egg } \\
\text { weight } \\
\text { (grams) }\end{array}$ & $\begin{array}{c}\text { total egg } \\
\text { weight } \\
\text { (kgrams) }\end{array}$ & $\begin{array}{l}\text { aggres- } \\
\text { siveness }\end{array}$ \\
\hline $\begin{array}{l}\text { R.4 } \\
\text { R.5 } \\
\text { S.3 } \\
\text { S.8 } \\
\text { R.2 } \\
\text { S.6 } \\
\text { R.7 } \\
\text { Bl.8 } \\
\text { Bl.7 } \\
\text { G.2 } \\
\text { Bl.6 } \\
\text { B.7 } \\
\text { R.1 } \\
\text { R.8 } \\
\text { R.6 } \\
\text { R.3 } \\
\text { Bl.1 } \\
\text { Bl.4 } \\
\text { Bl.2 } \\
\text { S.1 } \\
\text { W.2 } \\
\text { S.4 } \\
\text { G.7 } \\
\text { G.3 }\end{array}$ & $\begin{array}{r}1 \\
2 \\
3 \\
4 \\
5 \\
6 \\
7 \\
8 \\
9 \\
10 \\
11 \\
12 \\
13 \\
14 \\
15 \\
16 \\
17 \\
18 \\
19 \\
20 \\
21 \\
22 \\
23 \\
24\end{array}$ & $\begin{array}{l}70 \\
62 \\
62 \\
63 \\
64 \\
72 \\
59 \\
61 \\
63 \\
58 \\
71 \\
56 \\
61 \\
66 \\
64 \\
60 \\
73 \\
62 \\
67 \\
60 \\
68 \\
71 \\
66 \\
72\end{array}$ & $\begin{array}{l}57.8 \\
63.3 \\
57.8 \\
58.5 \\
66.1 \\
59.8 \\
56.8 \\
58.7 \\
63.1 \\
58.5 \\
65.6 \\
56.2 \\
55.2 \\
66.2 \\
63 \\
58.2 \\
60.3 \\
63 \\
56.3 \\
62.7 \\
62.9 \\
59.4 \\
60.4 \\
53\end{array}$ & $\begin{array}{l}4.046 \\
3.927 \\
3.588 \\
3.688 \\
4.231 \\
4.310 \\
3.356 \\
3.583 \\
3.978 \\
3.395 \\
4.664 \\
3.150 \\
3.371 \\
3.713 \\
4.037 \\
3.493 \\
4.405 \\
3.906 \\
3.755 \\
3.762 \\
4.278 \\
4.224 \\
3.988 \\
3.818\end{array}$ & $\begin{array}{r}334 \\
137 \\
51 \\
142 \\
72 \\
70 \\
179 \\
129 \\
71 \\
129 \\
150 \\
278 \\
169 \\
134 \\
64 \\
41 \\
79 \\
55 \\
97 \\
71 \\
109 \\
129 \\
106 \\
107\end{array}$ & $\begin{array}{l}\text { W. } 3 \\
\text { B.2 } \\
\text { S.5 } \\
\text { S.7 } \\
\text { B.8 } \\
\text { G.6 } \\
\text { W.4 } \\
\text { S.2 } \\
\text { G.1 } \\
\text { Bl.3 } \\
\text { G.4 } \\
\text { B.5 } \\
\text { G.8 } \\
\text { B.6 } \\
\text { B.3 } \\
\text { Bl.5 } \\
\text { B.4 } \\
\text { W.5 } \\
\text { W.6 } \\
\text { B.1 } \\
\text { G.5 } \\
\text { W.8 } \\
\text { W.7 } \\
\text { W.1 }\end{array}$ & $\begin{array}{l}25 \\
26 \\
27 \\
28 \\
29 \\
30 \\
31 \\
32 \\
33 \\
34 \\
35 \\
36 \\
37 \\
38 \\
39 \\
40 \\
41 \\
42 \\
43 \\
44 \\
45 \\
46 \\
47 \\
48\end{array}$ & $\begin{array}{r}73 \\
63 \\
55 \\
58 \\
57 \\
68 \\
62 \\
64 \\
45 \\
39 \\
62 \\
63 \\
1 \\
63 \\
62 \\
44 \\
63 \\
59 \\
42 \\
51 \\
70 \\
64 \\
55 \\
67\end{array}$ & $\begin{array}{l}60.8 \\
59.9 \\
65.7 \\
58.6 \\
60.6 \\
60.4 \\
64.5 \\
60.5 \\
61.8 \\
61.6 \\
59.4 \\
59.6 \\
53.0 \\
57.1 \\
65.2 \\
63.5 \\
61.3 \\
59.4 \\
54.7 \\
59.7 \\
64.5 \\
62.0 \\
65.1 \\
61.3\end{array}$ & $\begin{array}{l}4.440 \\
3.775 \\
3.617 \\
3.399 \\
3.458 \\
4.109 \\
4.005 \\
3.874 \\
2.783 \\
2.403 \\
3.684 \\
3.758 \\
0.053 \\
3.598 \\
4.049 \\
2.794 \\
3.868 \\
3.500 \\
2.298 \\
3.017 \\
4.515 \\
3.970 \\
3.581 \\
4.116\end{array}$ & $\begin{array}{r}95 \\
199 \\
49 \\
80 \\
97 \\
110 \\
44 \\
62 \\
132 \\
81 \\
86 \\
66 \\
58 \\
65 \\
23 \\
202 \\
105 \\
58 \\
18 \\
98 \\
18 \\
98 \\
0 \\
0\end{array}$ \\
\hline $\begin{array}{l}\text { Total } \\
\text { resp. } \\
\text { mean }\end{array}$ & - & 1551 & 60.1 & 92.666 & 2903 & $\begin{array}{l}\text { Total } \\
\text { resp. } \\
\text { mean }\end{array}$ & - & 1350 & 60.8 & 82.664 & 1844 \\
\hline
\end{tabular}

Table 3. Rank, aggressiveness and egg production in flock I during the period of 6/1 to 23/3 1964 
E. H. DIJKMAN AND OTHERS

\begin{tabular}{|c|c|c|c|c|c|c|c|c|c|c|c|}
\hline $\begin{array}{l}\text { hen } \\
\text { nr. }\end{array}$ & rank & $\begin{array}{l}\text { number } \\
\text { of eggs }\end{array}$ & $\begin{array}{c}\text { average } \\
\text { egg } \\
\text { weight } \\
\text { (grams) }\end{array}$ & $\begin{array}{c}\text { total egg } \\
\text { weight } \\
\text { (kgrams) }\end{array}$ & \begin{tabular}{|l} 
aggres- \\
siveness
\end{tabular} & $\begin{array}{l}\text { hen } \\
\text { nr. }\end{array}$ & rank & $\begin{array}{l}\text { number } \\
\text { of eggs }\end{array}$ & $\begin{array}{c}\text { average } \\
\text { egg } \\
\text { weight } \\
\text { (grams) }\end{array}$ & $\begin{array}{c}\text { total egg } \\
\text { weight } \\
\text { (kgrams) }\end{array}$ & \begin{tabular}{|l} 
aggres- \\
siveness
\end{tabular} \\
\hline R.4 & 1 & 34 & 59.85 & 2.035 & 225 & R.3 & 25 & 31 & 61.22 & 1.898 & 30 \\
\hline R.5 & 2 & 27 & 65.22 & 1.761 & 72 & S.5 & 26 & 26 & 68.46 & 1.780 & 25 \\
\hline R. 8 & 3 & 29 & 58.41 & 1.694 & 85 & G.6 & 27 & 35 & 62.51 & 2.188 & 41 \\
\hline S.3 & 4 & 31 & 60.45 & 1.874 & 52 & S.7 & 28 & 26 & 61.42 & 1.597 & 46 \\
\hline W.2 & 5 & 32 & 64.12 & 2.052 & 94 & G.4 & 29 & 27 & 58.70 & 1.585 & 9 \\
\hline R. 2 & 6 & 30 & 69.33 & 2.080 & 52 & B.3 & 30 & 32 & 66.50 & 2.128 & 18 \\
\hline G.7 & 7 & 32 & 64.96 & 2.079 & 156 & B.8 & 31 & 26 & 62.65 & 1.629 & 98 \\
\hline Bl.1 & 8 & 37 & 61.47 & 2.272 & 56 & W.4 & 32 & 27 & 65.95 & 1.781 & 46 \\
\hline Bl. 8 & 9 & 23 & 58.80 & 1.354 & 65 & W.3 & 33 & 34 & 62.56 & 2.127 & 42 \\
\hline R.7 & 10 & 27 & 57.81 & 1.561 & 93 & G.8 & 34 & - & - & - & 5 \\
\hline R.1 & 11 & 25 & 55.52 & 1.388 & 117 & Bl. 3 & 35 & 18 & 64.05 & 1.153 & 22 \\
\hline S.8 & 12 & 29 & 58.86 & 1.707 & 41 & W.8 & 36 & 31 & 63.48 & 1.968 & 99 \\
\hline G.2 & 13 & 29 & 59.51 & 1.726 & 45 & W.1 & 37 & 32 & 58.86 & 1.988 & 55 \\
\hline B.7 & 14 & 26 & 56.19 & 1.461 & 109 & B.4 & 38 & 30 & 62.56 & 1.877 & 38 \\
\hline Bl. 6 & 15 & 35 & 69.42 & 2.430 & 48 & B.5 & 39 & 30 & 61.80 & 1.854 & 11 \\
\hline S.1 & 16 & 24 & 65.62 & 1.575 & 53 & W.6 & 40 & 26 & 55.65 & 1.447 & 19 \\
\hline B1.2 & 17 & 30 & 57.30 & 1.719 & 91 & S.2 & 42 & 34 & 63.39 & 2.155 & 37 \\
\hline B1.7 & 18 & 29 & 66.69 & 1.917 & 56 & W.5 & 42 & 16 & 60.18 & 0.963 & 37 \\
\hline S.4 & 19 & 32 & 62.00 & 1.984 & 72 & B.6 & 43 & 31 & 58.51 & 1.814 & 57 \\
\hline S.6 & 20 & 33 & 61.96 & 2.054 & 16 & G.5 & 44 & 31 & 66.83 & 2.072 & 29 \\
\hline Bl.4 & 21 & 33 & 65,51 & 2.162 & 61 & W.7 & 45 & 26 & 64.88 & 1.687 & 40 \\
\hline B. 2 & 22 & 29 & 63.65 & 1.847 & 176 & G.1 & 46 & - & - & - & 22 \\
\hline R.6 & 23 & 31 & 65.25 & 2.023 & 46 & B.1 & 47 & 30 & 59.07 & 1.772 & 46 \\
\hline G.3 & 24 & 31 & 54.38 & 1.686 & 75 & B1.5 & 48 & - & - & - & 2 \\
\hline $\begin{array}{l}\text { Total } \\
\text { resp. } \\
\text { mean }\end{array}$ & - & 718 & 61.76 & 44.441 & 1956 & $\begin{array}{l}\text { Total } \\
\text { resp. } \\
\text { mean }\end{array}$ & - & 599 & 54.55 & 37.463 & 874 \\
\hline
\end{tabular}

Table 4. Rank, aggressiveness and egg production in flock I during the period of 24/3 to 30/4 1964. 


\begin{tabular}{|c|c|c|c|c|c|c|c|c|c|c|c|}
\hline $\begin{array}{l}\text { hen } \\
\text { nr. }\end{array}$ & rank & $\begin{array}{c}\text { number } \\
\text { of eggs }\end{array}$ & $\begin{array}{c}\text { average } \\
\text { egg } \\
\text { weight } \\
\text { (grams) }\end{array}$ & $\begin{array}{c}\text { total egg } \\
\text { weight } \\
\text { (kgrams) }\end{array}$ & $\begin{array}{l}\text { aggres- } \\
\text { siveness }\end{array}$ & $\begin{array}{l}\text { hen } \\
\text { nr. }\end{array}$ & rank & $\begin{array}{l}\text { number } \\
\text { of eggs }\end{array}$ & $\begin{array}{c}\text { average } \\
\text { egg } \\
\text { weight } \\
\text { (grams) }\end{array}$ & $\begin{array}{c}\text { total egg } \\
\text { weight } \\
\text { (kgrams) }\end{array}$ & $\begin{array}{l}\text { aggres- } \\
\text { siveness }\end{array}$ \\
\hline R.4 & 1 & 53 & 58.09 & 3.079 & 148 & W.8 & 24 & 48 & 61.02 & 2.949 & 111 \\
\hline R.5 & 2 & 43 & 65.00 & 2.795 & 108 & G.6 & 25 & 53 & 65.21 & 3.234 & 96 \\
\hline R.7 & 3 & 38 & 57.26 & 2.176 & 164 & B. 2 & 26 & 48 & 58.00 & 3.130 & 190 \\
\hline S. 3 & 4 & 53 & 58.06 & 3.077 & 115 & W.3 & 27 & 55 & 59.82 & 3.290 & 92 \\
\hline Bl. 7 & 5 & 48 & 63.75 & 3.060 & 119 & G.4 & 28 & 48 & 54.05 & 2.865 & 53 \\
\hline R. 2 & 6 & 48 & 69.48 & 3.335 & 81 & B.7 & 29 & 20 & 60.12 & 1.081 & 71 \\
\hline R. 8 & 7 & 43 & 56.77 & 2.441 & 70 & B. 8 & 30 & 43 & 60.65 & 2.585 & 95 \\
\hline B1.2 & 8 & 51 & 56.20 & 2.866 & 254 & S. 5 & 31 & 39 & 68.92 & 2.688 & 47 \\
\hline W.2 & 9 & 50 & 64.90 & 3.245 & 133 & W.4 & 32 & 49 & 60.96 & 2.974 & 68 \\
\hline Bl. 6 & 10 & 53 & 68.83 & 3.648 & 100 & Bl. 3 & 33 & 6 & 66.83 & 0.401 & 78 \\
\hline Bl.1 & 11 & 56 & 62.08 & 3.477 & 92 & B. 3 & 34 & 51 & 62.13 & 3.169 & 54 \\
\hline S.6 & 12 & 29 & 42.58 & 1.235 & 81 & W.6 & 35 & 40 & 53.67 & 2.147 & 78 \\
\hline Bl.8 & 13 & 34 & 59.91 & 2.037 & 45 & S.8 & 36 & 47 & 60.66 & 2.851 & 26 \\
\hline S.1 & 14 & 46 & 62.76 & 2.887 & 128 & B.4 & 37 & 47 & 61.08 & 2.871 & 71 \\
\hline R.6 & 15 & 52 & 62.54 & 3.252 & 105 & S.2 & 38 & 50 & 66.20 & 3.310 & 50 \\
\hline Bl.4 & 16 & 52 & 64.63 & 3.361 & 97 & W.1 & 39 & 53 & 60.47 & 3.205 & 41 \\
\hline G.3 & 17 & 57 & 51.83 & 2.929 & 291 & B.5 & 40 & 43 & 58.05 & 2.496 & 27 \\
\hline R.1 & 18 & 43 & 55.99 & 2.457 & 87 & G.5 & 41 & 28 & 46.79 & 1.310 & 48 \\
\hline S.4 & 19 & 50 & 60.58 & 3.029 & 137 & G.1 & 42 & - & - & - & 65 \\
\hline R.3 & 20 & 56 & 57.33 & 3.215 & 38 & B. 6 & 43 & 45 & 59.20 & 2.664 & 77 \\
\hline G.7 & 21 & 41 & 58.54 & 2.400 & 50 & W.7 & 44 & 42 & 64.40 & 2.705 & 84 \\
\hline G.2 & 22 & 40 & 57.60 & 2.393 & 73 & B.1 & 45 & 50 & 53.54 & 2.677 & 121 \\
\hline S.7 & 23 & 20 & 61.44 & 1.152 & 63 & Bl. 5 & 46 & 17 & 56.29 & 0.957 & 49 \\
\hline $\begin{array}{l}\text { Total } \\
\text { resp. } \\
\text { mean }\end{array}$ & - & 1056 & 59.83 & 63.546 & 2579 & $\begin{array}{l}\text { Total } \\
\text { resp. } \\
\text { mean }\end{array}$ & - & 922 & 57.31 & 55.559 & 1692 \\
\hline
\end{tabular}

Table 5. Rank, aggressiveness and egg production in flock I during the period of 1/5 to I/7 1964 . Note: W.5 and G.8 not present (had died).

\begin{tabular}{|c|c|c|c|c|c|c|c|}
\hline \multirow[b]{2}{*}{ period } & \multirow[b]{2}{*}{ groups of hens present } & \multicolumn{6}{|c|}{ mean rank of group: } \\
\hline & & $\begin{array}{l}\text { reds } \\
\text { (R.) }\end{array}$ & $\begin{array}{c}\text { silvers } \\
\text { (S.) }\end{array}$ & $\begin{array}{c}\text { blacks } \\
\text { (Bl.) }\end{array}$ & $\begin{array}{c}\text { greens } \\
\text { (G.) }\end{array}$ & $\begin{array}{l}\text { blues } \\
\text { (B.) }\end{array}$ & $\begin{array}{c}\text { whites } \\
\text { (W.) }\end{array}$ \\
\hline $\begin{array}{l}1 / 5-1 / 7^{\prime} 64 \\
9 / 7-13 / 7^{\prime} 64 \\
14 / 7-16 / 7^{\prime} 64 \\
17 / 7-22 / 7^{\prime} 64 \\
23 / 7-28 / 7^{\prime} 64 \\
29 / 7-26 / 8^{\prime} 64\end{array}$ & $\begin{array}{l}\text { R.; S.; Bl.; G.; B.; W. } \\
\text { B.; W. } \\
\text { G.; B.; W. } \\
\text { Bl.; G.; B.; W. } \\
\text { S.; Bl.; G.; B.; W. } \\
\text { R.; S.; Bl.; G.; B.; W. }\end{array}$ & $\begin{array}{l}9.0 \\
- \\
\frac{-}{18.0}\end{array}$ & $\begin{array}{l}22.1 \\
- \\
\overline{-} \\
21.9 \\
24.1\end{array}$ & $\begin{array}{l}17.7 \\
\overline{-} \\
12.0 \\
13.0 \\
18.3\end{array}$ & $\begin{array}{c}28.0 \\
- \\
10.0 \\
14.4 \\
20.4 \\
22.6\end{array}$ & $\begin{array}{r}33.0 \\
9.3 \\
13.3 \\
20.1 \\
25.3 \\
30.1\end{array}$ & $\begin{array}{r}30.0 \\
5.6 \\
9.6 \\
12.6 \\
14.9 \\
16.7\end{array}$ \\
\hline
\end{tabular}

Table 6. Mean rank of the 6 groups of flock I before, during and after rebuilding the flock. 


\begin{tabular}{|c|c|c|c|c|c|c|c|c|c|c|c|}
\hline $\begin{array}{l}\text { hen } \\
\text { nr. }\end{array}$ & rank & $\begin{array}{l}\text { number } \\
\text { of eggs }\end{array}$ & $\begin{array}{c}\text { average } \\
\text { egg } \\
\text { weight } \\
\text { (grams) }\end{array}$ & $\begin{array}{c}\text { total egg } \\
\text { weight } \\
\text { (kgrams) }\end{array}$ & $\begin{array}{l}\text { aggres- } \\
\text { siveness }\end{array}$ & $\begin{array}{l}\text { hen } \\
\text { nr. }\end{array}$ & rank & $\begin{array}{l}\text { number } \\
\text { of eggs }\end{array}$ & $\begin{array}{c}\text { average } \\
\text { egg } \\
\text { weight } \\
\text { (grams) }\end{array}$ & $\begin{array}{c}\text { total egg } \\
\text { weight } \\
\text { (kgrams) }\end{array}$ & $\begin{array}{l}\text { aggres- } \\
\text { siveness }\end{array}$ \\
\hline R.5 & 1 & 40 & 64.0 & 2.561 & 164 & Bl.7 & 22 & 36 & 68.4 & 2.463 & 9 \\
\hline W.2 & 2 & 44 & 64.3 & 2.839 & 110 & R.6 & 23 & 33 & 64.1 & 2.118 & 59 \\
\hline R.4 & 3 & 40 & 61.1 & 2.442 & 76 & G.6 & 24 & 48 & 59.4 & 2.852 & 45 \\
\hline Bl. 2 & 4 & 45 & 56.0 & 2.519 & 92 & S.2 & 25 & 38 & 66.9 & 2.543 & 68 \\
\hline W.6 & 5 & 42 & 60.0 & 2.520 & 73 & S.5 & 26 & 42 & 69.0 & 2.858 & 66 \\
\hline Bl.1 & 6 & 44 & 61.1 & 2.688 & 51 & W.8 & 27 & 36 & 64.8 & 2.332 & 48 \\
\hline B1. 8 & 7 & 27 & 63.3 & 1.709 & $62^{\circ}$ & B.4 & 28 & 45 & 62.0 & 2.791 & 48 \\
\hline S.3 & 8 & 44 & 58.5 & 2.575 & 36 & R.8 & 29 & 21 & 55.4 & 1.163 & 39 \\
\hline G.3 & 9 & 47 & 51.1 & 2.401 & 134 & B. 6 & 30 & 34 & 61.7 & 2.098 & 36 \\
\hline Bl.6 & 10 & 48 & 70.6 & 3.392 & 52 & B.8 & 31 & 29 & 61.4 & 1.780 & 27 \\
\hline G.2 & 11 & 18 & 55.5 & 0.999 & 34 & S. 6 & 32 & 37 & 50.5 & 1.871 & 14 \\
\hline G.7 & 12 & 31 & 63.8 & 1.977 & 83 & S.7 & 33 & 27 & 61.6 & 1.662 & 13 \\
\hline W.4 & 13 & 39 & 65.2 & 2.541 & 39 & R.1 & 34 & 41 & 54.8 & 2.251 & 42 \\
\hline S.1 & 14 & 48 & 60.5 & 2.237 & 88 & B. 3 & 35 & 37 & 65.2 & 2.414 & 15 \\
\hline W.1 & 15 & 48 & 61.5 & 2.954 & 72 & S.8 & 36 & 30 & 54.8 & 1.732 & 10 \\
\hline Bl. 4 & 16 & 46 & 68.4 & 2.464 & 47 & B.1 & 37 & 45 & 56.7 & 2.550 & 80 \\
\hline W.3 & 17 & 46 & 64.1 & 2.952 & 46 & W.7 & 38 & 33 & 65.0 & 2.145 & 64 \\
\hline R. 3 & 18 & 45 & 60.0 & 2.702 & 21 & G.1 & 39 & - & - & - & 70 \\
\hline S.4 & 19 & 41 & 61.5 & 2.523 & 70 & B1.5 & 40 & 45 & 63.1 & 2.840 & 56 \\
\hline B. 2 & 20 & 35 & 63.9 & 2.236 & 114 & Bl. 3 & 41 & 1 & 66.0 & 0.066 & 1 \\
\hline G.4 & 21 & 43 & 60.6 & 2.605 & 31 & G.5 & 42 & 3 & 56.0 & 0.168 & 7 \\
\hline $\begin{array}{l}\text { Total } \\
\text { resp. } \\
\text { mean }\end{array}$ & - & 861 & 61.7 & 51.836 & 1495 & $\begin{array}{l}\text { Total } \\
\text { resp. } \\
\text { mean }\end{array}$ & - & 661 & 58.4 & 40.697 & 817 \\
\hline
\end{tabular}

Table 7. Rank and aggressiveness in flock I during the period of 29/7 to 26/8 '64. Egg production in flock I during the period of $1 / 7$ to $26 / 8$ ' 64 .

Note: R.2, R.7, G.8, B.5, B.7 and W.5 had died. 


\begin{tabular}{|c|c|c|c|c|c|c|c|c|c|c|c|}
\hline $\begin{array}{l}\text { hen } \\
\text { nr. }\end{array}$ & rank & $\begin{array}{l}\text { number } \\
\text { of eggs }\end{array}$ & $\begin{array}{l}\text { average } \\
\text { egg } \\
\text { weight } \\
\text { (grams) }\end{array}$ & $\begin{array}{c}\text { total egg } \\
\text { weight } \\
\text { (kgrams) }\end{array}$ & $\begin{array}{l}\text { aggres- } \\
\text { siveness }\end{array}$ & $\begin{array}{l}\text { hen } \\
\text { nr. }\end{array}$ & rank & $\begin{array}{l}\text { number } \\
\text { of eggs }\end{array}$ & $\begin{array}{l}\text { average } \\
\text { egg } \\
\text { weight } \\
\text { (grams) }\end{array}$ & $\begin{array}{c}\text { total egg } \\
\text { weight } \\
\text { (kgrams) }\end{array}$ & $\begin{array}{l}\text { aggres- } \\
\text { siveness }\end{array}$ \\
\hline G.0 & 1 & 76 & 54.69 & 4.156 & 86 & R.0 & 21 & 65 & 49.46 & 3.215 & 76 \\
\hline R.4 & 2 & 70 & 49.93 & 3.495 & 70 & Bl.6 & 22 & 72 & 53.33 & 3.839 & 40 \\
\hline G.1 & 3 & 68 & 55.00 & 3.740 & 50 & G.5 & 23 & 3 & 44.33 & 0.133 & 31 \\
\hline W.4 & 4 & 70 & 50.03 & 3.502 & 119 & W.3 & 24 & 69 & 49.62 & 3.425 & 69 \\
\hline R.2 & 5 & 68 & 50.19 & 3.413 & 77 & Bl.4 & 25 & 68 & 55.01 & 3.747 & 5 \\
\hline G.3 & 6 & 39 & 57.59 & 2.246 & 56 & G.9 & 26 & 20 & 47.25 & 0.945 & 12 \\
\hline W.1 & 7 & 69 & 49.65 & 3.425 & 61 & G.8 & 27 & 47 & 52.79 & 2.481 & 26 \\
\hline B1.9 & 8 & 72 & 50.20 & 3.617 & 67 & W.9 & 28 & 42 & 50.59 & 2.125 & 19 \\
\hline W.0 & 9 & 71 & 55.93 & 3.971 & 108 & W.7 & 29 & 76 & 54.69 & 4.157 & 19 \\
\hline G.4 & 10 & 66 & 52.88 & 3.490 & 41 & B1. 2 & 30 & 66 & 51.36 & 3.390 & 30 \\
\hline G.6 & 11 & 56 & 53.57 & 3.000 & 41 & G.2 & 31 & 5 & 51.00 & 0.255 & 86 \\
\hline G.7 & 12 & 64 & 64.62 & 4.136 & 31 & R.6 & 32 & 42 & 54.98 & 2.309 & 76 \\
\hline B1.7 & 13 & 76 & 50.55 & 3.842 & 151 & R.8 & 33 & 68 & 51.09 & 3.494 & 7 \\
\hline B1.3 & 14 & 12 & 58.00 & 0.696 & 27 & R.9 & 34 & - & - & - & 12 \\
\hline R.3 & 15 & 37 & 54.37 & 2.012 & 36 & R.1 & 35 & 59 & 54.95 & 3.242 & 63 \\
\hline B1.0 & 16 & 73 & 50.67 & 3.699 & 36 & B1.5 & 36 & 58 & 52.86 & 3.066 & 29 \\
\hline B1.1 & 17 & 3 & 54.67 & 0.164 & 45 & R.7 & 37 & 74 & 53.83 & 3.984 & 22 \\
\hline W.8 & 18 & 68 & 51.79 & 3.522 & 39 & Bl. 8 & 38 & 72 & 51.62 & 3.719 & 9 \\
\hline W.5 & 19 & 66 & 57.24 & 3.778 & 31 & W.6 & 39 & 40 & 52.72 & 2.109 & 107 \\
\hline R. 5 & 20 & 1 & 51.00 & 0.051 & 98 & W.2 & 40 & 74 & 52.35 & 3.874 & 1 \\
\hline $\begin{array}{l}\text { Total } \\
\text { resp. } \\
\text { mean }\end{array}$ & - & 1125 & 53.63 & 59.955 & 1270 & $\begin{array}{l}\text { Total } \\
\text { resp. } \\
\text { mean }\end{array}$ & 一 & 1020 & 49.19 & 53.509 & 733 \\
\hline
\end{tabular}

Table 8. Rank and aggressiveness in flock II during the period of 4/7 to 30/8'64. Egg production in flock II during the period of $12 / 8$ to $4 / 11 ' 64$. 